\title{
From welfare state to participation society? Austerity measures and local sport policy in the Netherlands
}

\author{
Remco Hoekman ${ }^{\mathrm{a}, \mathrm{b}}$, Jan-Willem van der Roest ${ }^{\mathrm{b}}$ and Hugo van der Poel ${ }^{\mathrm{b}}$

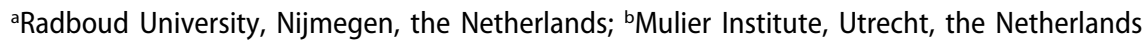

\begin{abstract}
This study investigates whether the shift from welfare state to participation society in the context of austerity in the Netherlands has had consequences for local sport policy. The central research questions are (1) do municipal sport budgets show evidence of a move away from classical welfare state values towards a participation society? and (2) do changes in local sport policy suggest a move away from classical welfare state values towards a participation society?

First, we analysed spending on sport across all Dutch municipalities. Second, we quantitatively and qualitatively analysed 104 municipal coalition agreements for the 2014-2018 governing period. The approach used was interpretive, focusing on dominant or hegemonic discourses or storylines within local sport policy.

It shows that Local sport policy in the Netherlands still hinges strongly on welfare state values and has not yet been hit by serious austerity measures. We found no evidence of a neoliberal slant or an emphasis on free-market and private entrepreneurship. Rather, the accent is on an expanded role for voluntary sport clubs (VSCs) in operating sport facilities and as policy implementer. We conclude that the shift in narrative from classical welfare state to participation society has, as yet, had limited effect on local sport policy.
\end{abstract}

\section{ARTICLE HISTORY}

Received 3 February 2017

Accepted 15 September 2017

\section{KEYWORDS}

Economic crisis;

neoliberalism; sport policy; voluntary sport clubs; sport facilities

\section{Introduction}

Similar to the United Kingdom's 'Big Society', which offers a distinctive narrative to legitimate cuts in public services (Bach 2012), the Netherlands has introduced the idea of the 'participation society' to frame the impetus for its austerity measures. The king, speaking for the Dutch government, invoked the term in his first annual address:

Undeniably, people in our modern network and information society are more outspoken and independent than in the past. Combined with the need to reduce the government deficit, this leads to a gradual change from the classical welfare state to a participation society. Everyone who is able, is asked to take responsibility for their own life and environment. (Rijksoverheid 2013, emphasis added)

We define austerity, following Blyth (2013), as a form of voluntary deflation set to adjust an economy to restore competitiveness. This is done by cutting state budgets, debts and deficits, among other means. Austerity, however, entails more than just cutbacks in public service provision. Austerity measures involve wider 'executive and managerial responses, aimed at restoring the fiscal balance, against the background of increasing demands for public services and political and public expectations of organizational performance' (Overmans and Noordegraaf 2014, p. 101). From this 
description, it is clear that austerity programmes also seek to reshape the organisations associated with public service provision.

To illustrate, austerity measures in the Netherlands have entailed a wide range of efficiency and structural changes in the way services are provided to citizens (Leisink et al. 2013). Particularly, responsibilities have been moved from national to local-level authorities, with greater emphasis on engaging civil society and shrinking the role of the state.

From a socio-ecological perspective, austerity-induced changes in the Dutch political and policy environment seem likely to have consequences for local sport policy and sport budgets. One would expect the shifting discursive context - from welfare state to participation society - to have influenced municipal spending on sport and the dominant 'storyline' (Fischer 2003) or discourse in local sport policy.

Thus, for starters, we expect austerity measures to have led to reduced municipal sport budgets. Földesi (2014, p. 22) called the prolonged recession that affected Europe between 2009 and 2013 'the worst one experienced since the Great Depression'. Speaking of grassroots sports, he concluded that 'considerably less money has been spent on this area than previously seen, and the investment in sport infrastructure has been dramatically reduced' (Földesi 2014, p. 29). An analyses of Dutch municipal coalition agreements for the 2010-2014 governing period drew a similar conclusion (Hoekman and Gijsbers 2010). These coalition agreements, which set policy plans for the upcoming governing period, indicated that local governments intended to cut spending on sport. A range of austerity measures was presented, including raising user fees for sport facilities, privatising sport facilities, closing facilities and postponing new builds and renovations of older facilities.

Furthermore, we expect national politics to influence local policies (Green and Collins 2008). As such, the altered discursive context - from welfare state to participation society - will likely have influenced the dominant 'storyline' or discourse in local sport policy. Indeed, a crisis is not seldom presented as a critical juncture that opens up an opportunity if not a necessity for radical welfare state reform (Vis et al. 2011). The previous economic crisis, in the 1980s, triggered deregulation, privatisation and withdrawal of the state from social services. At that time, these measures were presented as more or less unavoidable adjustments to a technologically advanced and globalised economy. This framing effectively problematises 'legitimate aspects of public service provision for both the nation as a whole as well as for individuals' (Adams 2011, p. 24).

Clarke (2004) linked the problematisation of public goods and dissolution of the welfare state to neoliberal tendencies. Neoliberalism is 'a theory of political economic practices that proposes that human well-being can best be advanced by liberating individual entrepreneurial freedom and skills within a framework characterized by strong private property rights, free markets and free trade' (Harvey 2005, p. 2). In the 1980s, neoliberal tendencies led to policies of deregulation and privatisation in the sphere of social welfare in the Netherlands and in other European countries (Bramham et al. 1993). This effected a move away from centralist and bureaucratic service delivery towards consumer-oriented approaches to service provision with a more prominent role for market forces (Gaster 1991, Fenwick and Bailey 1998). A wave of privatisation of sport facilities in the Netherlands and elsewhere in Europe (Hoekman and van der Poel 2009) was an expression of this.

It is possible that a new move away from public provision may now be under way, with local governments implementing a new wave of privatisation efforts favouring more business-like approaches to providing sport facilities (Kuhry and Jonker 2006). The tendency towards rolling back the local state and allowing more space for privatisation might in fact be more powerful this time around, because people and politicians are more used to the idea than they were in the 1980s. In this same vein, the expansion of the EU single market creates a legal obligation for all EU member states to reconsider their existing subsidy policies.

Neoliberal ideology, however, could be exhausted in the current day and age. The impacts of the recent recession have already been snatched upon by governments to further reshape public 
services. The United Kingdom did so utilising the 'Big Society' narrative (Bach 2012), which recognises the limitations of the earlier neoliberal-derived emphasis on free markets and private entrepreneurship. 'Big Society' denotes a wider perspective, signalling the government's ambition to shrink the state while increasing the role of civil society. Central in this is an emphasis on volunteering as a user-centred and cost-effective way to maintain public services in times of economic hardship (Bach 2012).

The Dutch government, by invoking the idea of a 'participation society', has also chosen such a wider perspective. It has called on its citizens to volunteer and take greater responsibility for themselves and their surroundings. The recent decentralisation of youth services and healthcare to the municipal level of government (Leisink et al. 2013) is an example of the Dutch ideal of bringing policy closer to the people, for more user-centred and cost-effective services. Moreover, because municipalities supposedly know the local situation best and are best placed to develop and implement integral policy measures, they, together with local civil society, are deemed able to provide tailored services more cheaply, which has legitimised severe budget cuts. We expect this new policy environment and the new participation-centred discourse to have consequences for the vocabulary used to present local sport policy. This could be evident as a revival of neoliberal freemarket terminology. Or, in line with the participation society discourse, it could take the form of greater expectations for the role of voluntary sport clubs (VSCs).

Our analyses investigated whether a shift from welfare state to participation society is indeed evident in local sport policy. We focused on the development of local sport budgets as an indicator of austerity within local sport policy. Furthermore, we examined local sport policy using an interpretive approach, focusing on dominant or hegemonic discourses or storylines, related to aspects of the welfare state, neoliberalism or a participation society (see e.g. Green 2006). In particular, we sought indications of a policy shift away from the welfare state.

This brings us to this study's central research questions: (1) Do municipal sport budgets show evidence of a move away from classical welfare state values towards the idea of a participation society? (2) Do changes in local sport policy suggest a move away from classical welfare state values towards the idea of a participation society? Answers to these questions will shed light on the position of sport, particularly local sport policy, in relation to the purported shift away from the welfare state to a participation society, framed in part as a result of necessary austerity measures.

\section{Methods}

To answer our research questions, we carried out a mixed-methods study with quantitative and qualitative research stages (Bryman 2006). The research was divided into two studies, with the second study made up of two research stages. The overall study can thus be understood as QUAN - quan $\rightarrow$ QUAL (cf. Morse 1991). In the first study, we examined all municipal budgets in the Netherlands over the 2010-2015 period to identify whether municipal spending on sport has indeed decreased, as claimed by Földesi (2014). In the second study, we analysed a selection of 104 municipal coalition agreements for the 2014-2018 governing period to identify policy changes and ambitions of the local authorities. This exercise used a technique similar to that in Hoekman and Gijsbers (2010), to allow comparisons. The sections below discuss the research procedure in detail.

\section{Study one}

To track sport spending, both absolute and in relation to overall municipal budgets, we analysed financial data from all municipalities in the Netherlands during the 2010-2015 period. Municipalities are obliged to register their financial statements in accordance with a Dutch reporting standard called IV3 models. This information is collected by Statistics Netherlands (CBS, n.d.) and was made available for the purpose of this study. Within these IV 3 models, sport income and 
expenditures are registered as budget items 530 'sport' and 531 'outdoor sport facilities'. Budget item 531 covers outdoor sports facilities. Budget item 530 covers indoor sport facilities plus activities to stimulate sport and other sport policy. We merged these two budget items and calculated the net expenditures per year for each municipality to obtain an overview of the sport expenditures of Dutch municipalities during 2010-2014. We related this net expenditure to total municipal expenditures in a given year and to total municipal expenditures within the leisure domain. This provided a broader perspective on sport expenditure. To ascertain the current situation as well as a future perspective, we also examined estimated expenses for 2015.

\section{Study two}

\section{Sampling procedure}

The second study consisted of quantitative and qualitative research stages, in line with the procedure in Hoekman and Gijsbers (2010). We selected 104 municipalities for this analysis. First, we included the Netherlands' four largest cities. We then used stratified sampling to select an additional 100 municipalities by number of inhabitants and region. The selected municipalities represent $48 \%$ of the Dutch population and $26 \%$ of all municipalities in the Netherlands in 2014.

The coalition agreements of the selected municipalities were collected in May 2014. These agreements set out the political strategy formulated by the municipal executive board, made up of the mayor and aldermen. These documents establish the policy plans for the various policy areas for the coming 4 years. Though municipal sport policy may be described in these documents, it is not one of the key elements.

\section{Quantitative stage}

After collecting the coalition agreements, we analysed the content of all the documents using an electronic keyword search strategy. Because we first wanted to determine the importance of sport in the coalition agreements, we included many terms that could indicate references to sport. We gave special attention to sport facilities, due to their importance in municipalities both financially and content-wise, and to topics that could relate to neoliberal tendencies (e.g. privatisation) and a participation society (e.g. VSCs). A wide range of words was included in the search because little consistency was found in the formulation of policies by the individual municipalities. For example, policies on public playgrounds were found to use either the Dutch word speelpleinen or the English term 'playgrounds'. Incorporating all keywords that could be associated with sport policies enabled us to find the sections referring to sport in the documents. Table 1 presents an overview of the keywords used.

\section{Qualitative stage}

After the quantitative content analysis, we qualitatively analysed all documents. To this end, we looked at the context in which the keywords appeared. We started by reading the texts around these keywords and coding text segments referencing aspects of the welfare state, neoliberal tendencies, participation society and austerity measures. This content analysis served to identify central discourses or storylines in local sport policy indicative of either a shift away from welfare state towards a participation society or impending austerity measures. We also identified implications for the local sport sector.

\section{Context: the role of local authorities in a contested welfare state}

In the Netherlands, local authorities or municipalities (404 in 2015) are the main governmental investors in sport. They contributed 93\% of public spending for sport in 2012 (CBS Statline 2015). The greatest portion, some $85 \%$, of municipal sport budgets goes to fund sport facilities' construction and operation (Hoekman and Breedveld 2013). Local sport policy is centred on facilitating sport. 
Table 1. Search terms used in quantitative document analysis, translated from Dutch.

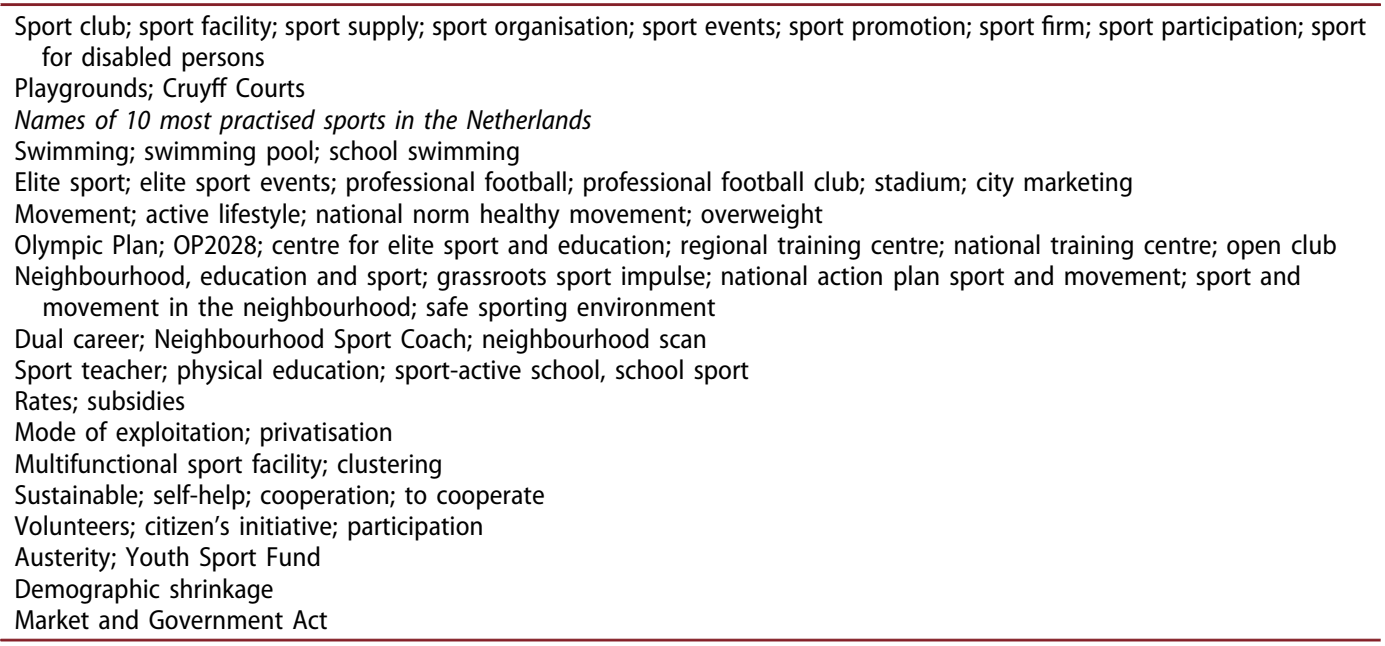

Capitalised search terms are names of policy programmes or sport-related policy terms.

Continuation of existing facilities and provision of new accommodations is highly demand-led. The strong growth in sport facilities in the 1960s and 1970s and their stabilisation in the 1980s reflects demographic and economic developments, as well as the needs of the educational system. Currently, the Netherlands has a dense sport infrastructure (Hoekman et al. 2016). The Dutch population is generally highly satisfied with the availability of facilities for sport (European Commission 2014).

Unlike in many other countries, the Dutch government's involvement in sport is not restricted or guided by a specific law (Ibsen and Seippel 2010, Hallmann and Petry 2013). While the national government encourages active participation in sports, it considers organisation of sport a matter for 'private' and 'local' initiatives. Sport policy is delegated to the municipal level and paid for from municipal budgets at the municipalities' discretion. However, as municipalities are under no legal obligation to provide sport facilities, and as sport is a leisure pastime, we may wonder whether municipalities uphold their investments in sports in times of austerity.

To understand the role of local authorities in the Dutch sport system, it is useful to place their activities into context. As Houlihan (2005, p. 176) notes, 'to understand the development of sport policy and its current salience it is important to appreciate the environment in which it emerged and continues to operate'. The widest perspective in this regard is that of the EU, with its expanding neoliberal 'single market'. This is followed by the national government, which recently decentralised many tasks in public service provision, and then local organisations, which provide for a mixed economy of sport provision.

The single EU market is more than just a new common or scaled-up version of the previously existing national markets. It is a much more 'free' market than these national markets. National policies, by extension, may be considered almost a form of 'false' competition by the state, allowed only under certain conditions. This conception of an unfettered free market has begun to influence existing market regulation. In 2014, the Netherlands translated the EU regulations on competition into the Market and Government Act. For local sport policy, this means that subsidising sport facilities - so that they can be rented out to VSCs below the cost price - is no longer allowed, as this creates false state competition for private entrepreneurs. For the time being, there is an escape route: the municipal council declares a particular service, such as sports, a 'service in the general economic interest'. So far nearly all Dutch municipalities have used this pathway to continue subsidising sport facilities (Hoekman and van der Poel 2016).

From the perspective of the national government, it is relevant to point out that the Netherlands is by origin a welfare state, though the country now displays aspects of corporatism 
and social democracy. Esping-Andersen (1990) therefore labelled it a hybrid welfare state (cf. van Oorschot 2006). The Dutch welfare state has traditionally had paternalist features, with the strong and fortunate expected to care for the weak and disadvantaged (Vis et al. 2008). Indeed, the literal translation of the Dutch word for 'welfare state' is 'caring state' (verzorgingsstaat). However, while once considered an ideal worthy of pursuit, the welfare state is now contested, in part due to financial difficulties in upholding public services. This has led to implementation of an array of efficiency and structural changes in the way services are provided to citizens (Leisink et al. 2013). A major recent development is the earlier-mentioned shift of responsibilities from national to local authorities.

Locally, municipalities are part of a diverse sport provision landscape. Sport facilities are built and operated by private companies, foundations, clubs and local authorities, including mixed forms. Private companies, for example, may run swimming pools with a fixed subsidy from local government. The government, both local and national, plays a minimal role in provision of sport activities (Hallmann and Petry 2013, van der Werff et al. 2015). VSCs have long been a fixture in the Dutch sport landscape. Some 27,500 VSCs organise sport activities (van der Werff et al. 2015). They either operate their own facilities (e.g. for tennis, golf, watersports, equestrian pursuits, shooting and bowling) or rent accommodations from private owners (ibid.) or local authorities (e.g. for indoor sports, swimming, soccer and athletics). In cases where local authorities are involved, the fees paid by VSCs are typically below market rates.

\section{Results}

\section{Municipal spending on sport, 2010-2015}

Municipal spending on sport showed an upward trend prior to 2010 (CBS Statline 2015). However, considering the economic crisis that began in 2008, there is reason to believe that from 2010 onwards, less funding was available (Hoekman and Gijsbers 2010). Table 2 shows expenditures on sport. The table first presents the absolute amounts spent by municipalities. The second column presents an index of spending in relation to the first year of measurement, which is 2010 . The initial figures are related to total municipal expenditures in the third and fifth column.

From this table, it is clear that, in absolute terms and contrary to our expectation, spending on sport has been relatively stable - even though total spending by municipalities decreased by $12 \%$ during this period. This overall budget shrinkage led to an increased share of sport spending in the total municipal budgets in the 2010-2014 period, from 2.6\% to $2.8 \%$. Taking inflation into account, however, reveals a somewhat hidden reduction in sport spending, especially in the last 2 years (fourth column). Sport spending underwent a 3.0\% decrease in purchasing power between 2010 and 2014. Nonetheless, this is less than the intended cutbacks on sport that were noted in the coalition agreements for 2010-2014. Recall that these referred to austerity measures including raising user fees for sport facilities, privatisation and closing sport facilities.

Table 2. Net expenditures on sport in the Netherlands, indices and share of sport expenses in total budget, average of 404 Dutch municipalities, 2010-2015.

\begin{tabular}{lccccc}
\hline & $\begin{array}{c}\text { Net expenditures } \\
\text { (x million euro) }\end{array}$ & $\begin{array}{c}\text { Index } \\
\text { sport }\end{array}$ & $\begin{array}{c}\text { Index total } \\
\text { budget }\end{array}$ & $\begin{array}{c}\text { Index sport, including } \\
\text { inflation }\end{array}$ & $\begin{array}{c}\text { Share of sport in } \\
\text { budget (\%) }\end{array}$ \\
\hline 2010 & 1141 & 100 & 100 & 100 & 2.6 \\
2011 & 1149 & 101 & 98 & 98 & 2.6 \\
2012 & 1165 & 102 & 98 & 97 & 2.7 \\
2013 & 1190 & 104 & 93 & 97 & 2.8 \\
2014 & 1195 & 105 & 88 & 97 & 2.8 \\
2014 (Estimated) & 1154 & 101 & 86 & 93 & 2.8 \\
2015 (Estimated) & 1156 & 101 & 93 & $92^{\mathrm{a}}$ & 2.4 \\
\hline
\end{tabular}

${ }^{\text {a }}$ The expected inflation in 2015 is $1 \%$. 
The last two rows in the table present estimated budgets. In 2014, actual expenditures were higher than budgeted. This could again be the case in 2015. Or, the new coalition period could serve as the starting point for severe cutbacks in sport budgets. To determine whether this is to be expected, we now shift our attention to the coalition agreements for the 2014-2018 governing period.

\section{Sport policy and austerity measures}

Previously, Hoekman and Gijsbers (2010) found that sport, though not a key topic as there is no legal obligation to fund sport, is a significant item in most municipal policy programmes. Our analysis of the 2014-2018 coalition agreements reiterates this conclusion. Almost all municipalities (91\%) devoted attention to sport in their 2014-2018 policy programmes (compared to the $89 \%$ found in the 2010 study). Similar to findings from the earlier study, almost two-thirds of municipalities devoted an entire section of their document explicitly to sport policy. There seems to be a relation between a municipality's size and the likelihood that it will pay attention to sport (Table 3). This is not surprising, as larger municipalities also have more comprehensive coalition agreements, which leaves more space for coverage of sport. Still, sport receives considerable attention even in small municipalities' coalition agreements.

Sport facilities are by far the most important sport-related topic in the municipal policy programmes (Table 4). Some $79 \%$ of the municipalities mentioned 'sport facilities' in their document, comparable to the finding from the 2010 study (77\%). This is attributable to the large share of sport budgets that goes to fund sport facilities. VSCs were also frequently mentioned. Some $64 \%$ of the policy documents used this term. This is a considerable increase compared to the $57 \%$ found in the 2010 analysis and might indicate a move towards a participation society.

Compared to the 2010-2014 coalition agreements, there was a remarkable rise in terms related to austerity measures and privatisation. The 3 newcomers in the keywords top 10 were all somehow related to austerity. First, $26 \%$ of municipalities mentioned 'cooperation' in their policy programme. This might indicate pursuit of economies of scale or partnership with civil society (e.g. VSCs) to maintain sport facilities. Second, 'mode of operation' was mentioned by $23 \%$ of the municipalities, signalling a quest for more efficient ways to run facilities, including through

Table 3. Significance of sport in municipal coalition agreements.

\begin{tabular}{|c|c|c|c|c|c|}
\hline Size of municipality (inhabitants) & $\begin{array}{c}\text { Small } \\
(<25,000)\end{array}$ & $\begin{array}{c}\text { Medium } \\
(25,000-70,000)\end{array}$ & $\begin{array}{c}\text { Large } \\
(70,000-250,000)\end{array}$ & $\begin{array}{l}\text { Major cities } \\
(>250,000)\end{array}$ & Total \\
\hline $\begin{array}{l}\text { Separate section on sport in coalition } \\
\text { agreement }\end{array}$ & 54 & 61 & 67 & 100 & 63 \\
\hline $\begin{array}{l}\text { Sport mentioned in coalition } \\
\text { agreement }\end{array}$ & 75 & 94 & 100 & 100 & 91 \\
\hline$N$ & 24 & 49 & 27 & 4 & 104 \\
\hline
\end{tabular}

Table 4. Top 10 most mentioned sport-related terms in municipal coalition agreements.

\begin{tabular}{llr}
\hline & $\%$ & $N$ \\
\hline Sport facilities & 79 & 313 \\
Voluntary sport clubs & 64 & 209 \\
Movement & 29 & 57 \\
Swimming pool & 27 & 51 \\
Cooperation & 26 & 40 \\
Sport promotion & 24 & 34 \\
Mode of exploitation & 23 & 32 \\
Youth Sport Fund & 21 & 24 \\
Sport for disabled persons & 19 & 23 \\
Neighbourhood Sport Coach & 17 & 25 \\
\hline
\end{tabular}


privatisation and outsourcing responsibilities to VSCs. Finally, 'Youth Sport Fund' appeared in 21\% of the municipal programmes. Youth Sport Fund is an organisation that pays membership fees and sometimes provides sporting equipment for children and young people from lower income families. Municipal policymakers therefore seem to be paying greater attention to accessibility of sport to lower income youths. The ideas expressed with these austerity-related terms will become more clear in the discussion of the qualitative research stage, in which actual passages in the coalition agreements were examined.

\section{Three challenges for municipalities}

This section fleshes out the policy changes and arguments municipalities use to underpin shifts in sport policy and budgets. Three main challenges regarding sport policy were found in the municipal coalition agreements: more efficient use and operation of sport facilities, a larger role for sport clubs and a need to create financial safety nets to maintain sport accessibility for all. For each of these, a related discourse and storyline could be traced.

\section{More efficient use of facilities}

As mentioned, the Netherlands has a very dense sport infrastructure. Hence, many municipalities, particularly in regions with a shrinking population, argue the necessity and feasibility of making more efficient use of sport facilities. In particular, centralisation and clustering are proposed for making optimum use and raising the 'social return' of the remaining facilities:

Because of demographic changes, the lower number of youths and the aging of the population, we are going to centralise the sport facilities. (midsized municipality)

Some policy programmes explicitly mention closure of facilities. Many propose mergers between facilities as the best option for keeping sport facilities available and affordable. This is often framed as a response to changing demands, as demographic changes and the reduced youth population are said to necessitate changes in supply. Some municipalities, though unsure of what to do with the facilities they have, are hesitant to suggest clustering. They just pose the questions they are facing:

What facilities can be sustainably maintained and what facilities would be better concentrated in the larger villages? What other functions and activities can the facilities accommodate? (small municipality)

In the larger municipalities and major cities, the discussion is somewhat different. They do not face a shrinking population. City populations are growing. But municipal finances are overstretched, so they have to be prudent about what facilities they continue to support. Sport facilities with low occupancy or in need of renovation are being re-evaluated, particularly in areas where land is costly. In some cases, centralisation of facilities can yield both cost savings and direct income from land sales.

Many municipal programmes present the more efficient use of facilities as the only 'realistic' or pragmatic course. After all, who could oppose a more efficient use of ever-scarce tax monies? Some municipal programmes present the option of privatisation and a rolled back government role in a similar way, arguing that this will help keep sport affordable for municipalities. A midsized municipality formulated this as follows:

Regarding sports the municipality's role should be re-examined: from administrator to director. Savings could be generated with a smarter organisation of the operation of facilities and by opting for a reduced role of the municipality. Some of those savings can be used to keep sport accessible to all. (midsized municipality)

Thus, across the board, increased efficiency in sport facility operation is argued for, framed as a means of keeping sport available and affordable. Most municipalities do warn that cutbacks in sport funding will be required in the near future. However, these are, in most cases, presented as a 
'logical' consequence of reductions in total local government funds. Few suggestions could be found for an ideological conviction that local government should relinquish its role in providing local sport facilities to the private sector. Hence, this challenge is cast, in most cases, as a pragmatic one.

\section{A bigger role for VSCs}

Municipal policy programmes call for a larger role for VSCs and volunteers. The coalition agreements contain language actively encouraging VSCs to take more responsibility for the maintenance of the facilities they use. VSCs are expected to become more financially independent as well. In one large municipality, this is directly related to the cutbacks that need to be made:

In the coming years, the finances will further be re-evaluated. Providing facilities to VSCs for a too-low rent can no longer be maintained. We expect VSCs to become more and more independent. (large municipality)

In some cases, the road to more independence seems to lead to a process of privatisation or at least a first careful step in that direction. One small municipality put this as follows:

The new coalition wants to promote the VSCs' independence with regard to maintenance activities and examine options for further privatisation of sport facilities [to VSCs]. (small municipality)

To avoid rising membership fees, VSCs are being asked to make greater use of volunteers to reduce costs such as maintenance and to raise income by organising more paid activities. Some municipalities suggest that VSCs could or should cooperate with other VSCs to save money. The idea here is that sport facilities can be used more efficiently if VSCs work together. VSCs were sometimes even directed towards mergers:

The [municipal] executive board promotes cooperation between VSCs and we support VSCs that want to merge. (small municipality)

As with the efficiency challenge, this challenge is presented as a 'logical' consequence of the 'necessity' of adjusting sport budgets to the financial limitations the local authorities are confronted with. Interestingly, 'privatisation' in this context does not refer to a transfer of responsibilities, tasks and facilities to private enterprises, but to VSCs as volunteer organisations. The apparent hope is that if volunteers take over tasks from the municipality membership, fees will not be affected. When privatisation does mean a shift into the hands of a private enterprise, it is often presented as a means to make facilities 'cheaper'. The assumption here is that the commercial sector can somehow operate facilities more cost-effectively than the public sector can.

The subtext, again, reads as a pragmatic argument. Who could oppose to the idea of transferring facilities to the commercial sector, if the commercial sector can run them at lower cost than the municipality? Privatisation to VSCs is also in line with the notion of a participation society. Civil society is incorporated into the policy, and the focus on volunteering makes it possible for the state to take a step back.

\section{Creation of financial safety nets to maintain accessibility}

Municipalities still attach great value to the accessibility of sport. Thus, local policymakers still consider it their responsibility to provide access to sport for all and not rely entirely on the participation society. Especially in relation to the youth, municipalities emphasise that austerity measures should not compromise the ability of the less advantaged to participate in sport. The solution proposed in the municipal policy programmes is creation of 'safety nets'. Most municipalities reserve funds to sponsor membership fees for low-income youths:

If further austerity measures turn out to be needed, that should not lead to reduced sport participation among the youth. That means a safety net has to be created for those who cannot afford the membership fees. (midsized municipality) 
Many coalition agreements refer to the Youth Sport Fund, which pay for membership fees and sometimes also equipment for those who cannot afford it (Jeugdsportfonds 2014). A bigger role for this fund is desirable, according to some municipalities:

The Youth Sport Fund should be promoted as a way to make sport accessible and affordable for children. (large municipality)

Youth sports in general is a reoccurring topic in the policy programmes, but there is also considerable attention for lower socio-economic status groups and sport for the disabled. The increased attention for these groups suggests a 'welfarist' reflex in local sport policy. If and when cutbacks lead to higher membership fees, this is acceptable only insofar that sport accessibility is not compromised. Sport, apparently, is still seen as an activity that everybody should (be able to) participate in, as it fosters social cohesion, personal well-being and health while playing a role in countering the obesity epidemic. Because the largest benefits in these respects can be gained by disadvantaged groups, a safety net is considered essential. Explicitly or implicitly, most local governments still seem to consider sport as a merit good and as having positive external effects, and not simply as a service traded on the market and needing no government support.

\section{Discussion}

The introduction of this paper suggested that local sport policy might have been influenced by the move away from classical welfare state values to the idea of a participation society. We expected (1) sober local sport policy with declining municipal expenditures on sport and (2) a discourse within local sport policy indicative of a revival of neoliberalism or the notion of a participation society.

Regarding the first expectation, we found that municipal expenditures on sport remained stable from 2010 to 2014. Only when we factor in inflation is a slight (3.0\%) decrease in purchasing power evident. Yet, this cannot be considered a 'dramatic reduction' (Földesi 2014) and in fact contradicts the plans and expectations formulated in the municipal coalition agreements for the 2010-2014 governing period (Hoekman and Gijsbers 2010). We did find evidence of austerity in the general municipal budget, as local budgets did decrease over time while populations grew. Outlays on sport as a proportion of total local budgets therefore rose slightly, from $2.6 \%$ in 2010 to $2.8 \%$ in 2014. This provides a strong indication that grassroots sport has been relatively immune, thus far, to both the economic crisis and to neoliberal politics trying to slim down the welfare state.

However, budget cuts could merely be delayed, as estimated budgets for 2015 do indicate severe cuts. Public opinion is an important factor in shaping the timing, extent and pace of social spending cuts. For this and other political or institutional reasons, there seems to be a considerable gap between intentions and achievements (Vis et al. 2011). Or perhaps the intended budget cuts require more time than anticipated to realise. This suggestion is strengthened by the difference between the estimated budget for 2014 and actual spending in that year. Budget cuts were intended, but not carried through. In the end, the local government evidently allocated more money to sport than originally planned. Apparently, then, the value of sport is acknowledged at the local level and local forces are active in influencing politics with regard to sport.

Concerning the second expectation that the move towards a participation society has likely impacted the discourse in local sports policy, we argued that local sport policy can be seen as a stronghold of the welfare state. The challenges that municipal coalition agreements identify are best read as arguments for sober sport policy that engages civil society but is still hinged on the principles of the welfare state. Local governments still aim to keep sport accessible to all, especially those in need. They also take their responsibility in achieving this seriously, emphasising the role of the 'caring state'. Hence, the austerity measures described in the coalition agreements can best be understood as an expression of the Calvinistic culture of frugality with public monies, rather than a neoliberal slant. Sober local sport policies with a larger role for VSCs is a way to enable this. The expanded role for VSCs is in line with the participation society narrative. It also links with 
developments in the United Kingdom, where VSCs are being stimulated to participate in civic programmes related to health, education, social cohesion and employment (Houlihan and Green 2009).

The 'participation society' spoken of by the Dutch government is like a VSC writ large: volunteers and not civil servants organise sport activities and run competitions, keep the clubs alive and to a large extent maintain and operate sport facilities. The participation society notion presents VSCs as a user-centred and cost-effective vehicle for delivering public services in tough times, in line with elements of the Big Society in the United Kingdom (Bach 2012). However, the expanded social role of VSCs foreseen by local governments might be difficult for these organisations to fulfil (cf. Waardenburg 2016) and has not been received uncritically (see e.g. Bach 2012). Indeed, in the United Kingdom, the Big Society has been judged a failure, unable to deliver on its original goals and ineffective in reaching those most in need (Civil Exchange 2015). Why then should the participation society in the Netherlands be more successful?

The increased efficiency (and effectiveness) that municipalities seek would require VSCs to adopt a more business-like approach, capitalising on the values of independence, autonomy, self-motivation and initiative that are assumed to be key in VSC management (cf. Nagel et al. 2015). Yet, already, multiple studies have questioned the realism of VSCs as policy implementers (Skille 2008, Harris et al. 2009). An expansion of VSCs' tasks as part of a move towards a participation society might therefore be less straightforward than foreseen within the coalition agreements.

Returning to the concept of neoliberalism (Harvey 2005), we could conclude that the cutbacks articulated in the coalition agreements point to a neoliberal slant (e.g. privatisation). However, the references do not suggest reliance on the free-market or the private sector. Taking references to privatisation as an illustration, the coalition agreements refer to VSCs not private entrepreneurs as the new owners of sport facilities. Furthermore, the signs of neoliberalism read as a call for more value for money spent and wise allocation of tax payers' money. While this is in line with the sober sport policy presented in the municipal policy programmes, we found no evidence of neoliberal assertions that the private sector is invariably good and the government is a 'necessary evil' (cf. Houlihan and Green 2009).

The absence of neoliberalism is further emphasised by the welfarist focus on the accessibility of sport. Municipalities argue that, when unavoidable, austerity measures must not affect the accessibility of sport and sport facilities. This is a good example of hybrid welfare state principles (van Oorschot 2006) and the felt responsibility of municipalities to contribute to the notion of sport for all and provide for the weak and disadvantaged ('caring state'). The coalition agreements emphasise the need for safety nets for those unable to pay for sport participation. Austerity measures generally do cause a greater segment of the population to fall into poverty, due to unemployment and cuts in government budgets.

Municipalities expect a rather narrow neoliberal focus would promote inequality, as shown in previous studies in other countries (e.g. Ostry et al. 2016). Evaluations of the Big Society in the United Kingdom also concluded that it was too difficult to mobilise the private sector for the common good (Civil Exchange 2015). Furthermore, from a participation society perspective, civil initiatives are understood as more likely to come from higher socio-economic groups than from lower socioeconomic groups (Bakker et al. 2011). Hence, local governments still feel the need to provide for lower socio-economic groups and continue governmental support for them to participate in sport. This is emphasised by the fact that virtually all local governments in the Netherlands have declared sports a 'service in the general economic interest', enabling them to opt out of the Market and Government Act for sport facilities (Hoekman and van der Poel 2016). In the Netherlands, as in other countries, maintaining access to sport is a central element of sport policy (Nicholson et al. 2011). This points to a classical welfare state regime rather than a neoliberal regime, in which sports are nothing more than a pastime that the market can cater for (Harvey 2005).

It is also notable that the coalition agreements position sport as an instrument to reach goals in other policy areas, such as health and social welfare. Under this merit good agenda (Liu et al. 2009), increased involvement is seen as socially desirable above and beyond any 
private benefit derived. A wider role of sport is generally acknowledged in sport policy, although it is debated whether sport can live up to this role (Coalter 2007). This social value of sport is what justifies public investment in sport, especially inclusion of disadvantaged groups which the market does not necessarily cater for and which are less likely to organise themselves and contribute to the participation society (cf. Verhoeven and Tonkens 2011). This might explain why sport has been relatively immune to the recent economic crisis, in fact registering increasing budgets relatively speaking. Other departments see sport as an valuable policy partner, given its instrumental merit. Furthermore, the fact that many tasks are performed by VSC volunteers instead of professionals makes sport a cost-effective partner for these other policy areas.

This also raises a danger: sport policy is vulnerable to policy spillovers (Houlihan 2012) from other departments faced with cuts and decentralisation of tasks. Sport could as a result become more utilised or manipulated (Houlihan 2000) by other policy sectors to achieve their goals (e.g. related to health and youth welfare). Indeed, municipal sport policy in the Netherlands is nowadays more about promoting health and social inclusion than about the benefits of sport participation itself (Hoekman and van der Maat 2017).

The strong focus on broader social welfare in local sport policy suggests that the welfare state is alive and well. Or perhaps, all along, sport is better seen as a vital element of the 'participation society'. In that sense, the participation society may be less a matter of replacing the welfare state, but of reemphasising the traditional role of the third, voluntary, sector, alongside the state and the market. At the same time, sport continues to have a highly positive profile, for the independent voluntary contribution it makes to public and commercial values such as health, city promotion, social cohesion and innovation. This could explain why developments in sport facility provision seem more affected by demographic and educational developments and changes in sport preferences than by shifts in the political landscape. This could, in turn, help explain the differences in the impact of the economic crisis on sport across Europe, in line with the various funding models and differences in national conceptions of the positive external effects of sport (Eurostrategies 2011).

With regard to the differences in the impact of the economic crisis on sport across Europe, it is important to acknowledge that the Netherlands is often presented as an outlier in comparative studies (see e.g. Hoekman, van der Werff, Nagel and Breuer 2015, Scheerder et al. 2017). This is related to the 'social configuration' of the Dutch sport policy system, with its strong sport sector and numerous VSCs playing a relatively large role in local policy. For the Netherlands, welfare pluralism (Chaney and Wincott 2014) seems to be an appropriate term to describe the framework for local sport policy. This conveys a strong focus on the common good of sport and the instrumental value of sport, alongside reliance on a participation society to maximise local involvement in sport and its social value.

To summarise, local sport policy in the Netherlands is still strongly hinged on the 'caring state'. Local sport budgets have so far been relatively immune to the economic crisis, seemingly due to the merit good agenda of sport. Nevertheless, sober sport policies are being promoted, however, maintaining accessibility of sport for all. There is no neoliberal slant favouring reliance on a free-market and private entrepreneurship. Rather, local government in the Netherlands tends towards a participation society with VSCs expected to play a wider role in the operation of sport facilities and as policy implementer in the future. Still, we conclude that the shift from classical welfare state to participation society has had limited consequences for local sport policy. Sport and VSCs, remain, as they have long been, a vital fixture in the local sport landscape and policymaking.

\section{Implications}

The sober sport policy promoted by municipalities has two primary implications. First, the planned austerity measures and call for more a business-like approach to sport provision put added 
pressure on VSCs. This may result in a mismatch between municipal policy and VSCs' own ambitions and abilities. Not all VSCs and volunteers (cf. Harris et al. 2009) are up to taking on more responsibilities and becoming a policy implementer. Some VSCs might simply lack the organisational capacity for these roles (cf. Misener and Doherty 2009). Previous research in the Netherlands found that few VSCs were entirely comfortable with their changing position in policy and society (van der Werff et al. 2015). Furthermore, the autonomy of the voluntary sector could be undermined by conditions attached to public financial support and the need for public accountability (Harris and Rochester 2001, Harris et al. 2009).

In considering the role of VSCs in delivering on policy objectives, respect for their diversity and autonomy must be maintained. While top-down incentives, such as subsidies from local government, can support and trigger VSC initiatives (Skille 2009), the value of autonomy should not be underestimated. Nagel et al. (2015) considers autonomy a key characteristic of sport clubs. Numerous reasons have been given for why involvement of sport clubs in wider social issues could be troublesome (cf. Nichols et al. 2005, Skille 2008). VSCs exist, in the first place, to pursue their own objectives, and not the objectives of state or market actors. Moreover, conclusions regarding the United Kingdom's Big Society make it crystal clear that community empowerment is easier said than done (Civil Exchange 2015). It therefore seems useful to first revitalise VSCs' support systems and stimulate them to professionalise their operations before calling on them to expand their tasks and perspectives.

A second implication is that local sport policy increasingly does not stand alone. Sport policy is influenced by the broader environment, from the EU down to the local organisational level. Local governments have thus far been able to avoid the Market and Government Act by using the escape route. But it is questionable how long this escape route will stand, as initial steps have already been taken to close it. Furthermore, from a local perspective, we found evidence of policy spillovers from other departments and sport being utilised to pursue goals in other sectors. Of course, there are benefits to this use of sports as a means. But sport policymakers should safeguard promotion of sport for its own sake.

Apart from these implications, the current study points to several avenues for further research. First, future research is needed to determine whether the recently announced austerity measures mark the year 2015 as a decisive turn in local sport spending. In a couple of years, we may conclude that there was only a delay in the expected 'dramatic reduction' and that the intentions expressed in the coalition agreements of 2010 and 2014 were achieved in the subsequent period. Moreover, research suggests that a new phase is beginning in which budgetary constraints are forcing political actors to make tough financial choices. This could produce increasingly sharp distributional conflicts (Vis et al. 2011). An example in the United Kingdom is the termination of the free swimming programme (O'Brien 2013).

Second, research is needed to examine the extent that the plans formulated in the coalition agreements are actually translated into sport policy programmes and affect the day-to-day business of sport provision.

Third, this study raises questions of the importance of municipal sport spending in safeguarding the accessibility of sport and sport participation. Will lower sport expenditures influence sport participation rates? Will safety nets prove able to ensure the inclusion of disadvantaged groups? And how important are the sport facilities that take up most of the sport budget to enable sport participation? In this regard, it would be fruitful to determine the extent that municipal sport expenditures and the presence of sport facilities correlate with sport participation rates and inclusion of disadvantaged groups.

Finally, on a more theoretical note, future research could examine the 'position' of sport in the welfare state. It seems rather obvious that grassroots sport is a vital element of the welfare state. However, it could be equally argued that grassroots sport is more a vital element of the 'participation society', invoking not a replacement of the welfare state but marking a rising importance of the existing third, voluntary, sector alongside the state and the market. 


\section{Disclosure statement}

No potential conflict of interest was reported by the authors.

\section{Funding}

This work was supported by the Nederlandse Organisatie voor Wetenschappelijk Onderzoek: [Grant Number 328-98008].

\section{Notes on contributors}

Remco Hoekman is a senior researcher at the Mulier Institute and a PhD candidate at the Department of Sociology, Radboud University Nijmegen, the Netherlands. His research interests include sport participation, sport facilities and sport policy and he has published various book chapters, articles and reports on these topics. He is President-Elect of the European Association for Sociology of Sport (EASS).

Jan-Willem van der Roest is a researcher at the Mulier Institute. He obtained a PhD in Governance at Utrecht University. His research areas of interest are governance of sports clubs, volunteering and sport policy.

Hugo van der Poel is director of the Mulier Institute. His interests and expertise lie in social theory, sport policy and sport facilities. He co-ordinates a research programme on Sport facilities and sport participation, funded by the Netherlands Organisation for Scientific Research, and holds various board memberships of sport organisations.

\section{References}

Adams, A., 2011. Between modernization and mutual aid: the changing perceptions of voluntary sports clubs in England. International journal of sport policy and politics, 3 (1), 23-43. doi:10.1080/19406940.2010.544663

Bach, S., 2012. Shrinking the state or the Big Society? Public service employment relations in an era of austerity. Industrial relations journal, 43 (5), 399-415. doi:10.1111/irj.2012.43.issue-5

Bakker, J., Denters, B., and Klok, P.J., 2011. Welke burger telt mee(r) in de doe-democratie? Beleid en Maatschappij, 38 (4), 402-418.

Blyth, M., 2013. The history of a dangerous idea. Oxford: Oxford University Press.

Bramham, P., et al., eds., 1993. Leisure policies in Europe. Wallingford: CAB International.

Bryman, A., 2006. Integrating quantitative and qualitative research: how is it done? Qualitative research, 6 (1), 97-113. doi:10.1177/1468794106058877

CBS (n.d.). Gemeente: iv3 modellen. Available from: http://www.cbs.nl/nl-NL/menu/informatie/deelnemersenquetes/decentrale- overheid/kredo/gemeente-of-gr/iv3- modellen/gemeente/default.htm [Accessed 11 November 2015]

Chaney, P. and Wincott, D., 2014. Envisioning the third sector's welfare role: critical discourse analysis of 'postdevolution' public policy in the UK 1998-2012. Social policy \& administration, 48 (7), 757-781. doi:10.1111/ spol.2014.48.issue-7

Clarke, J., 2004. Dissolving the public Realm? The logics and limits of neo-liberalism. Journal of social policy, 33 (1), $27-$ 48. doi:10.1017/S0047279403007244

Coalter, F., 2007. A wider social role for sport: who's keeping the score? London/New York: Routledge.

Esping-Andersen, G., 1990. The three worlds of welfare capitalism. Cambridge: John Wiley \& Sons.

European Commission, 2014. Special Eurobarometer 412. Sport and physical activity. Brussels: TNS Opinion \& Social.

Eurostrategies, 2011. Study on the funding of grassroots sports in the EU. Brussels: Eurostrategies.

Civil Exchange, 2015. Whose society? The final Big Society audit. London: Civil Exchange.

Fenwick, J. and Bailey, M., 1998. Decentralisation and reorganisation in local government. Public policy and administration, 13 (2), 26-39. doi:10.1177/095207679801300203

Fischer, F., 2003. Reframing public policy: discursive politics and deliberative practices. Oxford: Oxford University Press.

Földesi, G., 2014. The Impact of the Global Economic Crisis on Sport. Physical culture and sport. Studies and research, 63 (1), 22-30.

Gaster, L., 1991. Quality and decentralisation: are they connected? Policy and politics, 19 (4), 257-267. doi:10.1332/ 030557391782454142

Green, M., 2006. From 'Sport for All' to not about 'Sport' at all?: interrogating sport policy interventions in the United Kingdom. European sport management quarterly, 6 (3), 217-238. doi:10.1080/16184740601094936 
Green, M. and Collins, S., 2008. Policy, politics and path dependency: sport development in Australia and Finland. Sport management review, 11, 225-251. doi:10.1016/S1441-3523(08)70111-6

Hallmann, K. and Petry, K., eds. 2013. Comparative sport development: systems, participation and public policy. New York: Springer Science+Business Media.Sports Economics, Management and Policy 8.

Harris, S., Mori, K., and Collins, M., 2009. Great expectations: voluntary sports clubs and their role in delivering national policy for English sport. Voluntas, 20, 405-423. doi:10.1007/s11266-009-9095-y

Harris, S. and Rochester, C., 2001. Voluntary organisations and social policy in Britain. Basingstoke: Palgrave.

Harvey, D., 2005. A brief history of neoliberalism. Oxford: Oxford University Press.

Hoekman, R. and Breedveld, K., 2013. The Netherlands. In: K. Hallman and K. Petry, eds. Comparitive sport development: systems, participation and public policy. Sports Economics, Management and Policy 8. New York: Springer Science +Business Media.

Hoekman, R., Breedveld, K., and Kraaykamp, G., 2016. A landscape of sport facilities in the Netherlands. International journal of sport policy and politics, 8 (2), 305-320. doi:10.1080/19406940.2015.1099556

Hoekman, R. and Gijsbers, M., 2010. Sport in collegeprogramma's. Belangrijke bijzaak. Analyse van sport in collegeprogramma's gemeenten 2010-2014. 's-Hertogenbosch: W.J.H. Mulier Instituut.

Hoekman, R. and Van Der Maat, K., 2017. Monitor Lokaal Sportbeleid: faciliteren activeren en inspireren. Utrecht: Mulier Instituut.

Hoekman, R. and van der Poel, H., 2009. Sport: speelbal voor ruimtelijke ordening. Rooilijn, 42 (7), $458-465$.

Hoekman, R. and Van Der Poel, H., 2016. Beleid, beheer en financiering. In: H. van der Poel, K. WezenbergHoenderkamp, and R. Hoekman, eds. Sportaccommodaties in Nederland. Kaarten en kengetallen. Utrecht/ Nieuwegein: Mulier Instituut/Arko Sports Media, 236-259.

Hoekman, R., et al., 2015. A cross-national comparative perspective on sport clubs in Europe. In: C. Breuer, R. Hoekman, et al., eds. Sport clubs in Europe. Cham, Switzerland: Springer Science+Business Media.

Houlihan, B., 2000. Sporting excellence, schools and sports development: the politics of crowded policy spaces. European physical education review, 6 (2), 171-193. doi:10.1177/1356336X000062005

Houlihan, B., 2005. Public sector sport policy: developing a framework for analysis. International review for the sociology of sport, 40 (2), 163-185. doi:10.1177/1012690205057193

Houlihan, B., 2012. Sport policy convergence: a framework for analysis. European sport management quarterly, 12 (2), 111-135. doi:10.1080/16184742.2012.669390

Houlihan, B. and Green, M., 2009. Modernisation and sport: the reform of Sport England and UK Sport. Public Administration, 87 (3), 678-698. doi:10.1111/j.1467-9299.2008.01733.x

Ibsen, B. and Seippel, Ø., 2010. Voluntary organized sport in Denmark and Norway. Sport in society, 13 (4), $593-608$. doi:10.1080/17430431003616266

Jeugdsportfonds, 2014. Businessplan ambities \& strategie 2014-2017. Amsterdam: Jeugdsportfonds.

Kuhry, B. and Jonker, J., 2006. Maten voor gemeenten 2006. Een analyse van de prestaties van de lokale overheid. Den Haag: SCP.

Leisink, P., et al. (2013). Are there possibilities to influence austerity policy outcomes? A comparative study of social dialogue in local government in Italy, the Netherlands and the UK. Paper presented at the 10th European Conference of ILERA, Amsterdam: 20-22 June.

Liu, Y.-D., Taylor, P., and Shibli, S., 2009. Sport equity: benchmarking the performance of English public sport facilities. European sport management quarterly, 9 (1), 3-21. doi:10.1080/16184740802461686

Misener, K. and Doherty, A., 2009. A case study of organizational capacity in nonprofit community sport. Journal of sport management, 23 (4), 457-482. doi:10.1123/jsm.23.4.457

Morse, J.M., 1991. Approaches to qualitative-quantitative methodological triangulation. Nursing research, 40 (2), $120-$ 123. doi:10.1097/00006199-199103000-00014

Nagel, S., et al., 2015. Theoretical framework. In: C. Breuer, et al., eds. Sport clubs in Europe. Cham, Switzerland: Springer Science+Business Media.

Nichols, G., et al., 2005. Pressures on the UK voluntary sport sector. Voluntas, 16, 33-50. doi:10.1007/s11266-005-3231-0

Nicholson, M., Hoye, R., and Houlihan, B., 2011. Participation in sport: international policy perspectives. London/New York: Routledge.

O'Brien, D., 2013. Drowning the deadweight in the rhetoric of economism: what sport policy, free swimming, and EMA tell us about public services after the crash. Public administration, 91 (1), 69-82. doi:10.1111/j.14679299.2011.02019.x

Ostry, J.D., Loungani, P., and Furceri, D., 2016. Neoliberalism: oversold? Finance and development, 53 (2), $38-41$.

Overmans, J.F.A. and Noordegraaf, M., 2014. Managing austerity: rethorical and real responses to fiscal stress in local government. Public money \& management, 34 (2), 99-106. doi:10.1080/09540962.2014.887517

Rijksoverheid, 2013, September 17. Troonrede 2013. Available from: https://www.rijksoverheid.nl/documenten/toespra ken/2013/09/17/troonrede-2013 [Accessed 28 September 2015].

Scheerder, J., Willem, A., and Claes, E., eds., 2017. Sport policy systems and sport federations: a cross-national perspective. London: Palgrave Macmillan UK. 
Skille, E.Å., 2008. Understanding sport clubs as sport policy implementers a theoretical framework for the analysis of the implementation of central sport policy through local and voluntary sport organizations. International review for the sociology of sport, 43 (2), 181-200. doi:10.1177/1012690208096035

Skille, E.Å., 2009. State sport policy and voluntary sport clubs: the case of the Norwegian sports city program as social policy. European sport management quarterly, 9 (1), 63-79. doi:10.1080/16184740802461736

CBS Statline (2015). Overheid; uitgaven cultuur, sport en recreatie 1999 - 2012. Available from: http://statline.cbs.nl/ Statweb/publication/?DM=SLNL\&PA=70130NED\&D1 =43\&D2=0-3\&D3=|\&HDR=T\&STB=G1,G2\&VW=T [Accessed 28 September 2015]

van Der Werff, H., Hoekman, R., and van Kalmthout, J., 2015. Sport clubs in The Netherlands. In: C. Breuer, et al., eds. Sport clubs in Europe. Cham, Switzerland: Springer Science+Business Media.

van Oorschot, W., 2006. Making the difference in social Europe: deservingness perceptions among citizens of European welfare states. Journal of European social policy, 16 (1), 23-42. doi:10.1177/0958928706059829

Verhoeven, I. and Tonkens, E., 2011. Bewonersinitiatieven: partnerschap tussen burgers en overheid. Beleid en Maatschappij, 38 (4), 419-437.

Vis, B., van Kersbergen, K., and Becker, U., 2008. The politics of welfare state reform in the Netherlands: explaining a never-ending puzzle. Acta Politica, 43 (2-3), 333-356. doi:10.1057/ap.2008.11

Vis, B., van Kersbergen, K., and Hylands, T., 2011. To what extent did the financial crisis intensify the pressure to reform the welfare state. Social policy \& administration, 45 (4), 338-353. doi:10.1111/j.1467-9515.2011.00778.x

Waardenburg, M., 2016. Which wider social roles? An analysis of social roles ascribed to voluntary sports clubs. European journal for sport and society, 13 (1), 38-54. doi:10.1080/16138171.2016.1153883 